\title{
Przyczynek do dziejów Biblioteki Radzieckiej w Poznaniu
}

Spośród wielu godnych uwagi dokumentów życia społecznego przechowywanych w Bibliotece Uniwersyteckiej w Poznaniu chciałbym zwrócić uwagę na jeden - moim zdaniem - wart wnikliwej analizy i komentarza. Myślę tu o apelu, którego autorzy zwracają się do szerokiego kręgu odbiorców z uprzejmą prośbą, by zechcieli przekazywać na rzecz budowanej przez magistrat biblioteki wszelkich druków, w jakikolwiek sposób odnoszących się do Wielkiego Księstwa Poznańskiego.

Można - choć zdaję sobie sprawę, że jest to terminologiczne nadużycie apel ten potraktować jako swoistą próbę ustanowienia na obszarze Wielkiego Księstwa Poznańskiego instytucji egzemplarza obowiązkowego. W sytuacji, gdy nie było stosownych praw, które nakładałyby na wszystkich wydawców obowiązek bezpłatnego dostarczania bibliotece jednego egzemplarza swoich wydawnictw, inicjatorzy apelu zwracają się do nich z uprzejmą prośbą, by obowiązek taki na siebie nałożyli dobrowolnie i systematycznie przekazywali bibliotece miejskiej wszystkie ważne dla niej druki.

Magistrat apel swój w postaci litograficznie, dwustronnie zadrukowanej karty o wydłużonym formacie $34 \times 21 \mathrm{~cm}$, ozdobionej pieczęcią z herbem miasta i napisem w językach polskim i niemieckim w otoku, wydał 9 lipca 1874 roku. Jego dokładny zapis w języku polskim brzmi następująco:

Prośba

Zbywa o ile nam wiadomo dotąd na zbiorze wszystkich do Wielkiego Księstwa Poznańskiego odnoszących się w jedną całość zebranych druków, któreby każdemu przystępnemi były. A jednak zbiór taki, 
w możliwym komplecie, dla badaczów historyi i historyków naszego Księstwa największej byłby wartości.

Powzięliśmy więc zamiar, aby bibliotekę naszą przez zbiór podobny, któryby wiek nasz przetrwal, uzupełnić. Przedsięwzięcie jednak nasze, wtenczas tylko uskutecznić się może, jeżeli znajdzie czynną pomoc, a przede wszystkiem wsparcie całego Księstwa.

$\mathrm{Z}$ zaufaniem więc udajemy się do wszystkich jego władz i do wszystkich mieszkańców, oraz do wszyst.kich jego przyjaciól z tą usilıą Prośbą aby przedsięwzięcie nasze wspierać zechcieli.

Upraszamy mianowicie, aby nam wszelkie pisma i dokumenta odnoszące się do Wielkiego Księstwa Poznańskiego, do jego historyi i statystyki, do praw jego, handlu i przenysłu, do stosunków kościelnych i wyznaniowych, do wszystkich jego powiatów i miast, odnoszące się dalej do księstwa Warszawskiego i jego krajów poludniowo-pruskich, słowem tyczące tego wszystkiego, cokolwiek z prowincyą pozostaje w jakiemkolwiek związku, a to bez względu na przedmiot, bez względu na język w jakim są napisane, również bez względu na stanowisko, z jakiego zapatrywał się autor, albo przekazać nam zechcieli, albo do zakupu ofiarowali, lub też, gdzie się takowe znajdują, wskazali.

Każde dziełko choćby najmniej znaczące, każdy ol)jaw, zdawający się, że żadnej nie ma wartości, znajclzie w zbiorze, o jakim zamyślamy, swe miejsce i znaczenie. O podarunkach opatrzonych przez nas nazwiskiem dawcy, donosić będziemy publicznie, rady i wskazówki znawców każdocześnie z wdzięcznością przyjmując.

Magistrat

Apel został tegoż samego dnia wystosowany do niemieckojęzycznych mieszkańców Poznania i prowincji. Nie przedrukowała go ówczesna prasa poznańska, nie zamieszczono tez zadnej informacji o tej inicjatywie. W zbiorach Biblioteki Uniwersyteckiej obie wersje językowe są przechowywane w postaci luźnych kart i pochodzą z dawnego zasobu Historische Gesellschaft für die Provinz Posen. Natomiast w Bibliotece Poznańskiego Towarzystwa Przyjaciól Naık w przededniu II wojny światowej odezwa w języku polskim przechowywana była $\mathrm{w}$ - spalonej niestety w czasie zawieruchy wojennej - tece zawierającej korespondencje z tegoz roku (por. przypis 4). Mózina więc założyć, iź odezwy były kolportowane drogą korespondencyjną, celowo kierowane do osób i instytucji, które, według ich autorów, mogły pozytywnie ustosunkować się do zawartych w niej próśb.

Dokument ten prowokuje do postawienia kilku pytań. Kto stał personalnie za owym apelem? Do jakiej biblioteki mialy być kierowane zdobyte tą drogą druki? Czy publicznie informowano o osobach darczyńców? Wreszcie ostatnie: z jakim rzeczywistym odzewem apel ten się spotkał wśród mieszkańców Wielkicgo Księstwa Poznańskiego? 


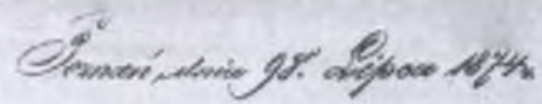
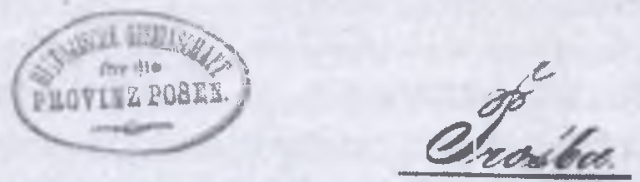

Q.

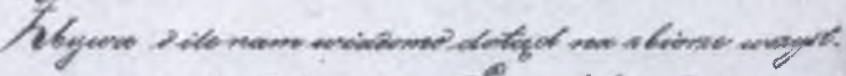

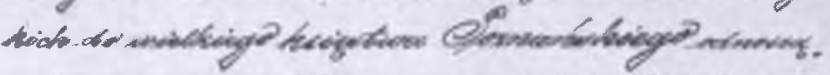

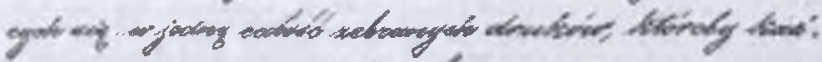

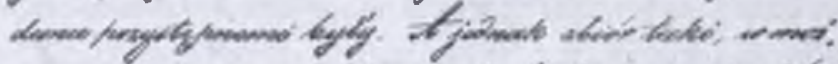

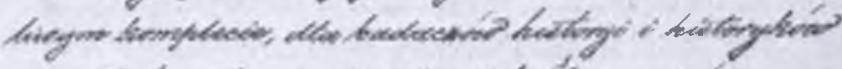

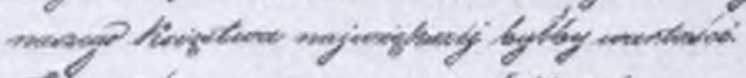

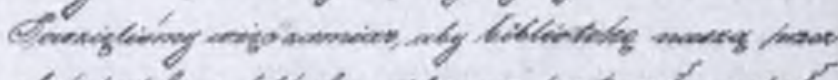

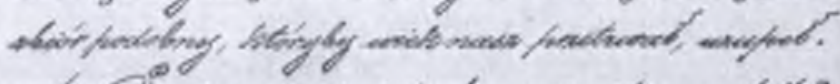

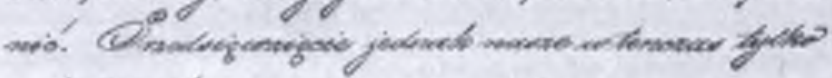

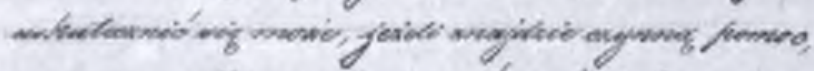

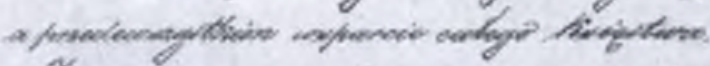

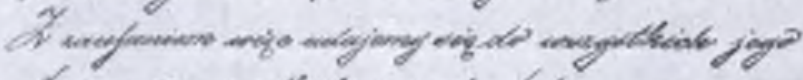

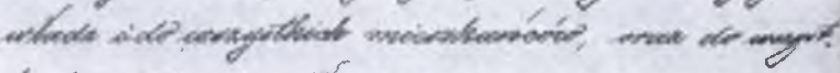

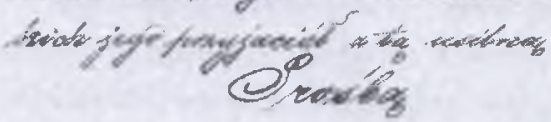

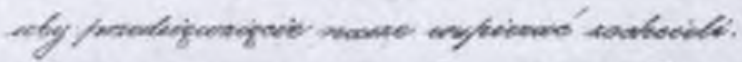

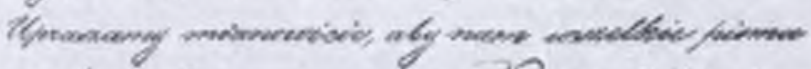

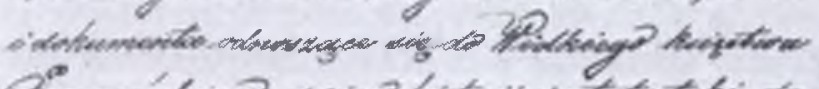

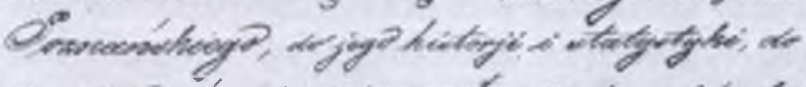

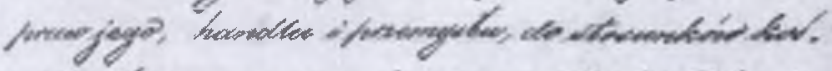

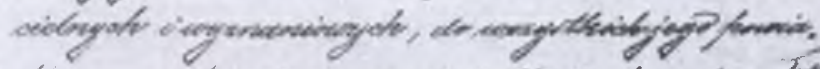

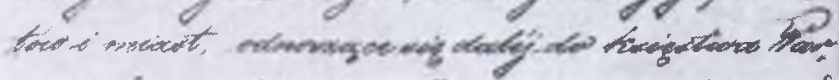

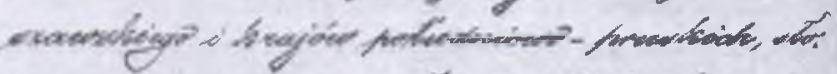

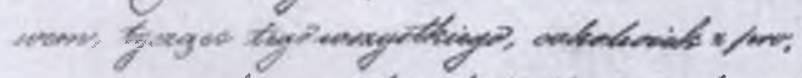

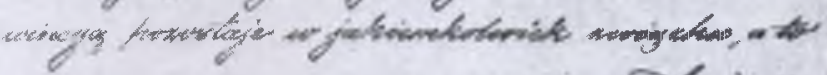




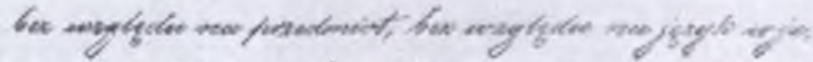

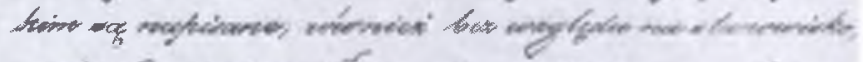

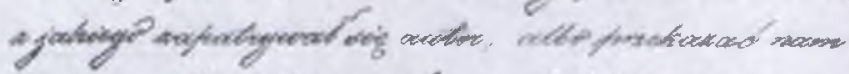

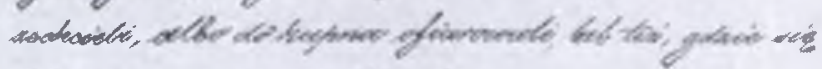

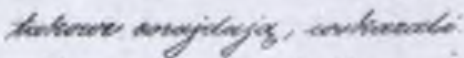

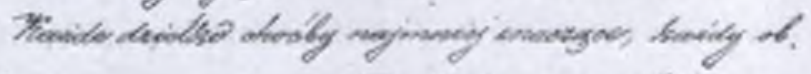

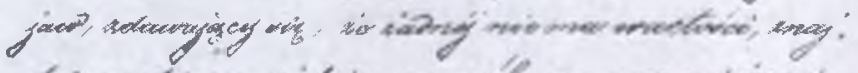

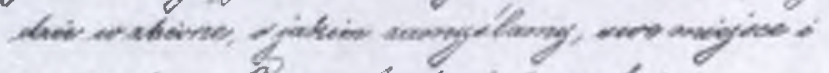

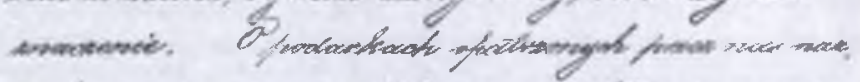

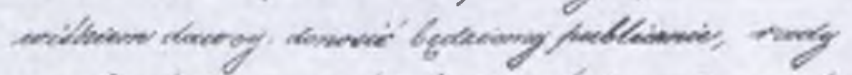

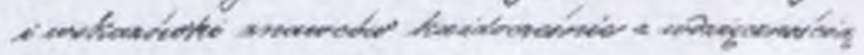

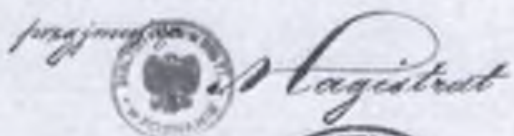

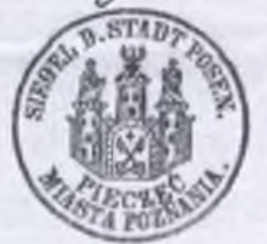

Apel Magistratu m. Poznania z 9.07.1874 roku, BU sygn. I14389 IIV28 
Zanim jednak postaramy się na nie odpowiedzieć, zatrzymajmy się jeszcze na chwilę przy użytym nieco na wyrost terminie ,egzemplarz obowiązkowy". Wiadomo, ze ówczesne biblioteki, działające na obszarze Wielkiego Księstwie Poznańskiego, książki do swych zbiorów pozyskiwały drogą kupna i - niewykluczone, że ta forma przeważała - przez różnego rodzaju darowizny. Zaadna z tych bibliotek nie miała prawa do otrzymywania egzemplarza obowiązkowego, w takim znaczeniu, w jakim pojęciem tym posługujemy się dzisiaj. Przepis prawny, regulujący te kwestie, został wprowadzony przez Fryderyka Wilhelma III w 1838 rokı i obowiązywal do roku 1876. W myśl tej ustawy drukarze i wydawcy działający na obszarach podległych władzy królewskiej byli zobowiązani do wysyłania po jednym egzemplarzu wydawanych przez siebie druków do dwóch berlińskich bibliotek: Uniwersyteckiej i Królewskiej. W Bibliotece Królewskiej w Berlinie - obecnie Deutsche Staatsbibliothek - były one rejestrowane w oddzielnych księgach, zależnie od dzielnicy, w której zostaly wydane ${ }^{1}$. Widać więc wyraźnie, że żadna z bibliotek Księstwa nie była objęta tym przywilejem, co oznacza, że żadna z nich nie dysponowała i nie dysponuje dziś w miarę kompletnym zbiorem wydawanych na obszarze Księstwa druków. Apel ten o tyle wydaje się ważny, ze przychylna reakcja adresatów, do których był skierowany, stwarzała realną możliwość powstania księgozbioru zawierającego piśmiennictwo regionalne o dıżym stopniı kompletności. Na marginesie warto dodać, że wspomniany przed chwilą inwentarz (noszący dziś nazwę Acta Posen III 1838-1876), zawierający dane o blisko 2,2 tys. pozycji (co stanowi około $30 \%$ całej ówczesnej produkcji wydawniczej Wielkopolski), pozwala na identyfikację 238 tytułów nierejestrowanych przez polskie bibliografie, niearchiwizowanych w żadnej polskiej bibliotece! ${ }^{2}$

Tak więc ówczesne biblioteki miasta Poznania mogły liczyć tylko na skromme zakupy, albo - jak już wspomniano - na dary. Biblioteka Poznańskiego Towarzystwa Przyjaciół Nauk mogła, jako instytucja powołana do życia przez wiedzione patriotycznymi pobudkami polskie społeczeństwo, liczyć w sposób szczególny na wsparcie darczyńców. Biblioteka ufundowana przez Edwarda Raczyńskiego w tym okresie bazowała na zakupach, w mniejszym stopniu korzystała z darów. Trzecia z największych, a więc Biblioteka Działyńskich budowała swe zbiory w oparciu o zakup.

${ }^{1}$ O problemie egzemplarza obowiązkowego pisała F. Krause, Die slavischen Verbindungen der Königlischen Bibliothek zu Berlin und der Aufbau ihres Slavica-Bestandes seit ihrer Gründung bis 1871, Leipzig 1976, s. 161-164.

${ }^{2}$ Por. A. Jazdon, Nieznane dzieuiętnastowieczne druki wielkopolskie w inwentarzu Deutsche Staatsbibliothek w Berlinie, „Studia Polonistyczne” t. 20. 1992, s. 59-80. 
Co mieli więc na myśli twórcy apelı, pisząc, iź książki te znajdą się w ,zbiorze, o jakim zanyślamy"? W grę mogłaby wchodzić Biblioteka Raczyniskiego, będąca júz od lat biblioteką, publiczną, Biblioteka Radziecka jako biblioteka magistratu lub - z ıwagi na charakter wskazanej w apelı literatury - biblioteka ıtworzona w ramach Historische Gesellschaft für die Provinz Posen. Przypomnijny, w apelı szczególny nacisk kładzie się na druki z zakresu szeroko rozumianej historii regionu, czyli tego obszaru, który był przedmiotem naukowych zainteresowań Towarzystwa.

Szkopuł w tyı, ze Towarzystwo powstanie dopiero 11 lat później i w rokı publikowania apelu nikt raczej jeszcze nie myślał o budowie mającej mı służyć biblioteki. Otwarcie archiwum państwowego w Poznaniu w 1869 rokı stworzylo nowe mózliwości do rozwoju badań historyczıych, gdyí pojawili się w mieście archiwiści i historycy przygotowani do ich prowadzenia. Kilka lat później, w rokı 1882, dyrektor archiwım Christian Meyer zacznie wydawać czasopismo, ZZeitschrift für Geschichte ınd Landeskinde der Provinz Posen", które - jak należy sądzić - miało zachęcić miejscowych badaczy i miłośników historii do bardziej aktywnego zainteresowania się historią regionu. Czasopismo bardzo szybko upadło, choć niewykluczone, ze pośrednio przyczyniło się do zawiązania w 1885 roku wspomnianego Towarzystwa ${ }^{3}$. Pozostaje więc Biblioteka Radziecka, co już przed wojną, w krótkiej notatce, stwierdził Andrzej Wojtkowskit, a co potwierdza zapis w - drukowanym kilka lat później - katalogı tej biblioteki".

Biblioteka Radziecka, której początki sięgają bardzo odległej, bo aż piętnastowiecznej przeszłości, w czasach, które nas interesują, była biblioteką bardzo skromną. Wynikało to zarówno ze zniszczeń dokonanych w jej zasobach $\mathrm{w}$ wiekach poprzednich, jak i ze stosunkowo małego zainteresowania magistratu jej rozbudlowa. Jak pisze, w poświęconym dziejom tej instytıcji szkicu, Zygmunt Zaleski, w pierwszej polowie XIX wieku w jej skład wchodziły prawie wyłącznie wydawnictwa periodyczne potrzebne tutejszej

\footnotetext{
${ }^{3}$ Por. K. Malinowski, Niemieckie Towarzystwo Historyczne u Poznaniu. Dzialalność w latach 1885-1919, „Przegląd Zachodni” 1990, nr 3, s. 1-18.

${ }^{4}$ A. Wojtkowski w dziale Zapiski Kroniki Miasta Poznania z 1930 roku (s. 280-281) umieścił notatkę zatytułowaną Zamiar rozszerzenia poznanskiej biblioteki radzieckiej z $1874 \mathrm{r}$., w której na podstawie dokumentu przechowywanego w Bibliotece PTPN w Tece Korespondencji z 1874 roku przytacza tekst apelu i wskazuje na hipotetycznego autora. Według niego apel odniósł pewien skutek i do biblioteki wpłynęła spora liczba ksiązek i broszur tematycznie związanych z Wielkim Księstwem Poznańskim. Zapał ten jednak szybko ostygł, ksiązki z działu historycznego systematycznie usuwano, co nakazywało kierować mu zainteresowanych materialami do historii Wielkopolski do innych, wskazanych przez siebie w dalszej części komentarza, bibliotek.

${ }^{5}$ Bücher-Verzeichniss der Raths-Bibliotehek zu Posen, Posen 1883.
} 
administracji do pełnienia jej codziennych powinności ${ }^{6}$. Dopiero w latach sześćdzisiątych tego wieku zaczęto gromadzić w niej książki. Wpływ roczny nie był jednak duży, o czym świadczą zapisy w pierwszym inwentarzu biblioteki, sporządzonym w 1874 roku przez znanego poznańskiego księgarza i antykwariusza Józefa Jolowicza. Wpisał on bowiem do niego 530 jednostek? Wspomniana inwentaryzacja dokonana zostala z inicjatywy burmistrza Jarosława Hersego. Był to drugi z kolei burmistrz miasta, który należał do, odgrywającej wówczas w Poznaniu poważną rolę, niemieckiej lewicy liberalnej, skupionej od 1861 rokı w Niemieckiej Partii Postępowej (Deutsche Fortschrittspartei), a od $1884 \mathrm{w}$ Niemieckiej Partii Wolnomyślnych (Dentsche Freisinnige Partei); cieszył się w mieście dużą popularnością. Od 1879 roku niemiecka lewica liberalna, przeciwstawiająca się brutalnym metodom germanizacyjnym, głównie dzięki właśnie pozycji Hersego, zdominowała życie polityczne mieszczaństwa poznańskiego ${ }^{9}$. Położył on, jak stwierdza Zaleski, duze zasługi dla biblioteki radzieckiej, gdyż rozpoczął ,staranne powiększanie biblioteki"1). Ambicja jego było zgromadzenie całego piśmiennictwa dotyczącego zarówno Poznania, jak i Wielkiego Księstwa Poznańskiego. Mózemy więc stwierdzić, że za apelem stał bez wątpienia wspomniany burmistrz Herse, a uzyskane książki wzbogacać miały Bibliotekę Radziecką.

Aktywność Hersego potwierdza lektura wstępu do wspomnianego katalogu, powstałego w końcówce jego rządów, w którym czytamy, íz na wzbogacanie księgozbioru zacząl on przeznaczać corocznie z budżetu kwotę 600 marek. Te niewielkie środki ,mogły służyć jedynie budowaniu księgozbioru podręcznego, co stanowiło podstawowy kierunek gromadzenia", który jednak, jak dalej stwierdzano, przy ciągle zmieniających się potrzebach trudno było uznać za „konkretny system” gromadzenia zasobu ${ }^{11}$. To zadecydowalo, że pozyskiwanie książek do nowego księgozbioru ma się odbywać według jednolitych zasad, spośród których najważniejszą ma być gromadzenie wszystkich druków dotyczących Wielkiego Księstwa Poznańskiego. Zakłarlano przy tym, ¿̇e księgozbiór taki tylko wówczas będzie „wartościową pomocą w badaniach i piśmiemnictwie historycznym", gdy będzie kompletny. To nakazało w roku 1874 zwrócić się listownie do władz i mieszkańców prowincji, do wszystkich ich przyjaciół i protektorów z prośbą

${ }^{6}$ Z. Zaleski, Bibljoteka Radziecka, w: Bibljoteki wielkopolskie i pornorskie, red. S. Wier(zyniski, Poznań 1929, s. 18.

' Ibidem.

${ }^{8}$ L. Trzeciakowski, Aktyuność polityczna poznaniaków, w: „Dzieje Poznania”, t. 2, cz.1., Poznan 1994, s. 374.

${ }^{9}$ L. Trzecikowski. op. cit., s. 390.

III Z. Zaleski, op. (it., s. 18.

"Bücher-V'erzeichniss..., s. |I]. 
o wsparcie zamierzenia. Spotkała się ona z życzliwym przyjęciem, co odnotowali autorzy apelu: ,nasza prośba nie pozostała bez odzewu i otrzymaliśmy kilka cennych darów, zwłaszcza w pierwszych latach"12.

Jak wspomniano, w roku rozpoczęcia akcji księgozbiór biblioteki liczył 530 woluminów. Zaleski wskazuje, że w 1880 roku biblioteka liczyła już 4300 woluminów, a w roku 1884 doszła do 5300 tomów ${ }^{13}$. Analiza zawartości katalogu wykazuje, iz najwyższym zarejestrowanym numerem inwentarzowym (zapewne w końcu 1882 roku, bo wstęp datowany jest na dzień 1 lutego 1883 roku) był numer 4434 . Niestety, katalog ten nie byl budowany konsekwentnie według jednolitych i czytelnych zasad. Niektóre tytuły zaznaczano pod jednym numerem, mimo iz były dwu- czy wielotomowe. Inne rozbijano, opatrując każdy tom oddzielnym numerem. Nierzadko, nadając dziełu jeden numer, zaznaczano, że w zbiorach jest kilka egzemplarzy tej pozycji. Katalog rejestrowal równiez czasopisma, których tytuły wymieniano czasem w ramach numeracji inwentarzowej, czasem poza nią. W niektórych przypadkach pod jednym numerem zapisywano caly - często kilkudziesięcioletni - ciąg, w innych poszczególnym rocznikom nadawano oddzielne numery. Wszystko to komplikuje wyliczenia. Zsumowanie liczby jednostek wedłıg zapisu w katalogu wykazuje niewiele ponad 4600 woluminów. Mớna więc założyć, iz w momencie, gdy dobiegało końca urzędowanie Hersego, biblioteka posiadala około 4600-5000 woluminów. Łatwo wyliczyć, że w okresie, gdy Herse byl burmistrzem, jej zbiory wzbogacily się o blisko 4,5 tys. jednostek. Średni przyrost roczny wynosił więc około 500 tomów, co uznać można za wynik bardzo dobry. Prowadzone od lat osiemdziesiątych ubiegłego wieku badania ( $w$ tym rejestracja dorobku wydawców wielkopolskich w wydzielonej bazie danych) pozwalają na stwierdzenie, że w trzeciej ćwierci XIX wiekı w Wielkopolsce wydawano rocznie okolo 200-250 wolıminów dzieł zwartych ${ }^{14}$. W bibliotece gromadzono, jak wspomniano, czasopisma, które uniemożliwiają dokonanie dokładnych porównań. Pamiętajmy także o tym, że ambicją Hersego było gromadzenie nie tylko książek czy czasopism wydawanych w Poznaniu i na terenie Wielkiego Księstwa Poznańskiego, ale równiėz wydanych gdziekolwiek, jeśli tematyczne związane były z Wielkopolską. Interesowało go również piśmiennictwo wcześniejsze, które wplywało do biblioteki jako dary. Następcy Hersego na systematyczne zakupy zaczęli przeznaczać jeszcze większe kwoty (np. w rokı 1887 aź 1170 marek) ${ }^{15}$, lecz

12 Bücher-Verzeichniss..., s. [2].

${ }_{13}$ Ibidem.

${ }^{14}$ A. Jazdon, Przeobrażenia wielkopolskiej oferty uydawniczej lat 1801-1918, „Kronika Wielkopolski" 1990, nr 4, (57), s.12.

${ }^{15}$ Z. Zaleski, op. cit., s. 19. 
równocześnie ograniczyli zakres gromadzonego piśmiennictwa, dostosowując go do potrzeb urzędu. Gromadzili głównie druki z zakresu prawa, techniki, gospodarki, uzupełniając je „ogólną literaturą komunalną”, wydawnictwami encyklopedycznymi, pracami dotyczącymi szkolnictwa, polityki spolecznej, spraw sanitarnych, politycznych itp. ${ }^{16}$ Jak stwierdza Zaleski, zbiór Hersego kłócił się z tymi załózeniami glównie z uwagi na swój historyczny charakter, zgromadzenie „zabytków dawniejszych" i fakt, i $\dot{z}$ materialy te stanowiły „w głównej mierze kompleks dzieł polskich". W trosce o pewną czystość profilu zbiorów prawie wszystkie książki polskie, łacińskie i stare książki niemieckie zdeponowano z czasem w Bibliotece Cesarza Wilhelma, a wydawnictwa źródłowe w Archiwum Państwowyn. Te informacje zdają się wskazywać jednoznacznie na charakter pozyskanego w tych latach w wyniku akcji Hersego materiału, co zostanie zweryfikowane w dalszej części artykułu.

Wydatkowane na zakup książek fundusze nie były jednak aż tak duże (wspomniane 600 marek), aby można za nie zbudować tak liczny i - jak można sądzić - dość wartościowy księgozbiór. Fakt ten pozwala sformułować opinię, że apel spotkał się z przyjaznym odzewem wśród szerszych kręgów społeczenstwa. Opinię tę potwierdza również Zaleski, gdy mówi, że większość książek zgromadzonych w bibliotece pochodziła z darów, stąd tak duża liczba dzieł wielkopolskich i poznańskich, ale odbiegających swą tematyką od założonego profilu organizowanej biblioteki ${ }^{17}$.

Zatrzymajmy się przez chwilę nad tą opinią, nie tylko po to, by ją uszczegółowić, ale by odpowiedzieć na pozostałe pytania, niejako sprowokowane przez apel z 1874 roku. Bardzo pomocna jest tutaj wnikliwa lektura wydanego w 1883 roku katalogu. We wstępie znajdujemy wykaz darczyńców, mózna zalożyć, ̇̇e byla to jedyna forma podziękowania za ich dary. Nie znajdziemy bowiem ich nazwisk na łamach poznańskiej prasy, a była to w tym czasie zwyczajowa forma honorowania zasług różnego rodzaju filantropów. W ten sposób, na przykład, publikując stosowne obwieszczenie, Biblioteka PTPN kwitowała hojność swoich ofiarodawców.

Wykaz ofiarodawców dla Biblioteki Radzieckiej zawiera łącznie 135 pozycji, z czego 41 to instytucje, a 94 - osoby prywatne. W pierwszej grupie znajdıjenny m.in. Królewskie Ministerstwa: Wojny (i oddzielnie, bez wymienienia konkretów, ,różne jego departamenty"), Sprawiedliwości, Kultury, Robót Publicznych - wszystkie z siedzibą w Berlinie. W drugiej grupie wymienić należy urzędy i instytucje poznańskie (Naczelne Prezydium, sąd, władze miasta); magistraty: Bydgoszczy, Bojanowa, Gniezna, Obrzycka, Strzelna, Wschowy; wiele instytucji wojskowych, m.in. z Erfurtu, Stargardu,

\footnotetext{
${ }^{16}$ It)idem.

${ }^{17}$ Ibidem.
} 
Szczecina, Strasslırga, Szprotawy, Wroclawia; Bibliotekę Uniwersytecką z Wrocławia, towarzystwa kredytowe i banki, instytucje kościelne, a nawet lożę masońską z Poznania. Wśród darczyńców prywatnych przeważają poznaniacy. Na liście tej odnajdujeny m.in.: Pawła Czwalinę, dra Ludwika Gąsiorowskiego, burmistrza J. Hersego, Kazimierza .Jarochowskiego, L11dwika Jażdżewskiego, Kazimierza Kantaka, dyrektora banku dra Samtera, profesora Gimnazjum Marii Magdaleny J. Schwemińskiego, dra Bolesława Wicherkiewicza. Licznie reprezentowani są także darczyńcy z Bydgoszczy (6), Trzemeszna (5), Krotoszyna, Piły, Wągrowca, Wschowy (po 3), wyprzedzając przedstawicieli: Gniezna, Inowrocławia, Kościana, Leszna, Nakła, Ostrowa, Pleszewa i Wrześni (po 2). Pojedyncze osoby nadesłały dary z: Adelnau, Buku, Grodziska, Kłecka, Lubostronia, Międzyrzecza, Obrzycka, Rawicza, Rogoźna, Szubina, Śmigla, Śremu i Torunia. Nazwiska większości z nich (poza hrabią Posadowskim z Krobi) nie powiedzą nam wiele. Warto wskazać, iż z pruską dokładnościa notowano także ich profesje, co pozwala stwierdzić, że najwięcej wśród nich było nauczycieli, dyrektorów szkół, urzędników, obok których odnajdujemy takize pastorów, kupców, a nawet muzyka. Na końcu należy przyjrzeć się grupie, z którą - jak wolno nam sądzić - autorzy apelu wiązali szczególne nadzieje. Mowa tu o wydawcach, księgarzach i drukarzach. Lista ta - co dziś należy stwierdzić z pewnym ubolewaniem - jest bardzo krótka: dwaj przedstawiciele Ostrowa: T. Hoffmann i J. Priebatsch oraz przedstawiciele Poznania: M. Jagielski, J. Jolowicz, J. Lissner, L. Merzbach, E. Röstel (zarządzający Drukarnią Deckera) oraz J.K. Zupański. Przy tym ostatnim nazwiskı znajdıjemy notatkę, ze „ofiarował billliotece kilkaset woluminów”. W ten sposób zapewne uhonorowano wyjątkową - na tle innych - hojność tego ofiarodawcy.

Bardziej wnikliwa lektura tej listy dość szybko pozwala zauważyć, że wiele osób i instytucji odpowiedziało na apel nie tyle z wewnętrznej potrzeby, ile niejako... z urzędu. Fakt, że rekrutowali się oni zarówno z różnych ośrodków niemieckich, jak i z wielu miast Wielkiego Księstwa Poznańskiego, zdawałby się zapewniać napływ zróżnicowanego tematycznie piśmiennictwa, prezentującego różne, uwzględniające lokalną specyfikę, punkty widzenia. Niestety, z prowincjonalnych ośrodków napływały dary tylko od pojedynczych osób, co antomatycznie przekreślało, tak ważną dla inicjatorów apelu, ideę, by projektowana przez nich biblioteka dysponowała kompletem wydawnictw wielkopolskich z określonych dziedzin.

W tej sytuacji wydatną pomoc w realizacji tego celu mogli okazać prowincjonalni drukarze, księgarze i wydawcy, ale tutaj rozczarowanie jest jeszcze większe. Na wspomnianej liście znaleźli się tylko dwaj prowincjonalni wydawcy i to w dodatku obaj pochodzący z tego samego miasta. Taka reakcja musi zaskakiwać - lata siedemdziesiąte to okres, w którym prowin- 
cjonalny ruch wydawniczy rozwijał się bardzo dynamicznie i wiele miast Wielkopolski miało swoje, często bardzo prężnie działające oficyny. Dość wspomnieć o Gnieźnie (tutaj bardzo aktywny był J.B. Lange), Inowrocławiu, Lesznie, Grodzisku, Międzyrzeczu, Pleszewie, Rawiczu, Rogoźnie, Śremie, Trzemesznie, Wolsztynie, Wschowie. Zapewne ową powściągliwość można do jakiegoś stopnia wytłumaczyć polsko-niemieckimi resentymentami. Wielı polskich wydawców nie widziało powodu, by wzbogacać swoimi książkami bibliotekę niemieckiego urzędu i życzliwie odnosić się do idei niechby nawet sensownej - firmowanej przez wysokiego niemieckiego urzędnika. Niezależnie od pobudek, jakie nimi kierowały, ich powściągliwość i pełen rezerwy dystans, przesądziły o tym, że wbrew intencjom organizatorów zbiory w projektowanej bibliotece nie mogły być kompletne.

Bardzo wyraźnie można to zauważyć, gdy porównamy zawartość kata$\operatorname{logu~z~zawartością~bazy~danych,~która~rejestruje~caly~dorobek~ówczesnych~}$ wydawców. Tylko 5\% wydanych w czasie trwania akcji książek znalazło się w Bibliotece Radzieckicj. Najlepszy pod tym względem był rok 1875, w którym - jak pamiętamy - rozpoczęła się akcja. $10 \%$ wydanych w Wielkopolsce ksiązek trafiło do biblioteki. Oczywiście, przytaczając te dane, ani przez chwilę nie zapomnialem, że biblioteka starała się pozyskiwać tylko te ksiązki, które odpowiadaly założonemu profilowi. Brak stosownych badań i analiz nie pozwala na podanie dokładnych liczb, ale mózna - bez ryzyka popełnienia błędı - stwierdzić, że w ofercie ówczesnych wydawców na pewno było znacznie więcej książek, które mieściły się w profilu biblioteki. W dalszej części szkicu powrócę do tego zagadnienia i postaram się wskazać na brak konkretnych dzieł, których nie ma w zbiorach, choć, ze względu na swą tematykę, winny się tam znaleźć. Tymczasem chciałbym wskazać na jeszcze jeden - moim zdaniem - interesujący szczegół.

W ciagu 10 lat - przypominam - biblioteka wzbogaciła się o liczbę woluminów, która dwukrotnie przekraczała produkcję wydawniczą calej prowincji. Oznacza to, że przeważająca ilość wpływów pochodzić musiała z ośrodków wydawniczych spoza Wielkopolski, z zapasów wydawców i księgarzy oraz prywatnych księgozbiorów indywidualnych ofiarodawców. Oczywiście pamiętam równię o tym, że pewna część książek pochodziła z zakupów. W ten sposól pozyskiwano zapewnie książki starsze, które uzupełniały budowany księgozbiór. Nie zmienia to jednak ogólnej oceny, iż wplywające do biblioteki tytuly z lat 1874-1882 w małym stopniu odzwierciedlają ówczesną globalną produkcję wydawniczą oraz dorobek w wybranych, wskazanych przéz organizatorów, zakresach dziedzinowych.

Spójrzmy, przed ostateczną oceną badanego zjawiska, na układ dziedzinowy zbudowanego zasobu. Skladał się on z siedemmastu części. Najobszerniejszy był dział pierwszy, w którym gromadzono literaturę treści ogólnej 
o całej prowincji, Poznaniı, poszczególnych okręgach i miastach. Liczył on 952 woluminy. Równiėz bardzo obszerny był dział VII zawierający literaturę z zakresu prawa, gdyż liczył 740 woluminów. Około 400 woluminów zawierały dwa następne działy dotyczące organizacji i zarządzania państwem, spraw gospodarczych, polityki społecznej. Najmmiej, bo tylko 55 woluminów zawieral dział poświęcony wojskowości.

Ważniejsze zdają się jednak inme konkluzje wynikające z analizy katalogu. Otóź przeszło 82,5\% zgromadzonej w zasobie literatury napisanej było w języku niemieckim. Tylko w $12,8 \%$ była to literatura polskojęzyczna, a w 4\% łacinskojęzyczna. Pozostała $(0,7 \%)$ wydana była w języku francuskim, choć notujemy pojedyncze tytuły w językach angielskim i czeskim. W ¿̇aden sposób te proporcje nie odzwierciedlają struktury językowej piśmiennictwa wydawanego w tym czasie w Wiclkopolsce. Przeczy to takze, przytoczonej juź poprzednio, opinii Zaleskiego, iż materiały te stanowiły „W głównej mierze kompleks dzieł polskich", co przesądziło o ich późniejszym wycofaniu ze zlbiorów. Przeważają dzieła wydane w Berlinie i innych miastach Niemiec. Wicle z tytułów, które zakwalifikowano do trzech najobszerniejszych działów, swym zakresem tematycznym wykracza poza, nawet najogólniej pojmowaną, problematykę regionalną. Jedyny dział, w którym przeważały ksiązki w języku polskim, to dział XVII „Varia. Miscellanea”. Wyniknęło to z problemów z zaklasyfikowaniem wielu tych książek do któregokolwiek z wcześniejszych działów merytorycznych. Ale téz obok dzieł np. filozoficznych A. Cieszkowskiego, K. Libelta czy B. Trentowksiego znajjujemy tı zbiory legend, klechd, podań, powiastki, utwory poetyckie, dzicła poświęcone muzyce. Zawartość tego działı zrlaje się potwierdzać spostrzeżenie Zaleskiego, ze częśc dzieł nie do końca odpowiadała przyjętym zasadom gromadzenia zasobu, co nie oznacza, że usprawiedliwiona jest opinia, że w poszczególnych działach znalazły się ksiązki przypadkowe i takie, których obecności w tym właśnie miejscu nie da się uzasadnić. To prawda, że część z nich ma charakter bardzo ogólny, część dotyczy imnych regionów, ale nie można powiedzieć, ̇̇e ich obecność w bibliotece o tak wyraźnie zarysowanym profilu jest calkowicie bezzasadna. Mogą na przykład służyć studiom porównawczym, konfrontowaniu doświadczé́ imnych regionów z wlasnymi itp. To prawda, jak w każdej bibliotece, która w dość krótkim czasie musi uporać się z napływem większej liczby książek, zdarzały się tu pewne błędy. I tak na przykład zdziwienie budzi obecność w dziale poświęconym szkolnictwu i oświacie takich książek, jak: Astronomia ludouna J. Fontany, J. Molińskiego Gramatyka łaciniska dla szkół gimnazjahych, elementarze autorstwa m.in. M. Brzeskiego czy E. Estkowskiego. Można zgodzić się z oceną, że te ostatnie niespecjalnie pasowaly do charakterı zbiorı, choć, rzecz jasna, można uzasadniać, że słuzyły badaniu metod nauczania w tutejszych szkolach. 
Zaskakujący jest również - powracam do myśli wyrażonej wcześniej brak dość waínych i przylegających do profilu biblioteki ksiązek polskich. Należą do nich: Mariana Długoborskiego Gospodarka włościańska w okolicy Poznania (1873); Jana Sadowskiego Spótki pożyczkowe w zastosowaniu do gospodarstwa wiejskiego (1873); Romana Szymańskiego Statystyka ludności polskiej w zaborze pruskim (1873); Kazimierza Czannieckiego Herbarz polski (1875-1882); Pawła Fabisza Opis historyczny kościoła w Ostrowie (1875); Sprawa polska w parlamencie niemieckim w 1875 roku (1875), Kodeks Dyplomatycznego Wielkiej Polski (od 1877); H. Nierzewuskiego Sprawa polska po Kongresie Berlinskim (1878); J. Falkowskiego Wspominania z roku 1848 i 1849 (1879); komplet wydawanych przez J.K. Żupańskiego Pamiętników z ósmnastego wieku; wiele ustaw, statutów, mów pogrzebowych zawierających cenne informacje biograficzne czy listy pasterskie M. Ledóchowskiego; publikacje E. Calliera, W. Kosińskiego, J. Łukowskiego, I. Łyskowskiego, M. Morawskiego, F. Rakowicza, A. Szamarzewskiego, K. Szulca; komplet czy wyczerpujący zestaw opracowań naukowych H. Feldmanowkiego, K. Jarochowskiego, J. Korytkowskiego, E. Likowskiego, F. Skarbka, Koźmianów, Rzepeckich; zestawie map powiatów opracowywanych przez A. Hilschera, a takie niemieckie opracowania typu G. Igla Heimatskunde der Provinz Posen (1875) czy M. Bära Die Bamberger bei Posen zugleich ein Beitrag zur Geschichte der Polonisirungstrebungen in der Provinz Posen (1882). Moźna by tę listę kontynuować, sądzę jednak, że te przykłady wystarczająco dobitnie potwierdzają teze, ze mimo, godnych szacunku, ambicji jej organizatorów, biblioteka daleka była od kompletności.

Jeszcze jedna opinia Z. Zaleskiego zasługuje na kilka słów komentarza. Powiada on, że znaczna część zbioru miała charakter historyczny, jako że znalazło się w nim sporo ,zabytków dawniejszych". To prawda, 200 starodruków (książek wydanych do 1800 roku), które znalazły się w księgozbiorze, zasługuje na uwage, ale jest to zaledwie $4,6 \%$ całego zasobu. Z pierwszej połowy wiekı XIX pochodziła co piąta ksiązka, z lat 1851-1873 przeszło 38\%, a z lat 1874-1882 przeszło 33\%. Całość uzupełnial zbiór 21 rękopisów. Mózna zatem powiedzieć, pamiętając o wyraźnie określonym profilu biblioteki, ze przeszło $70 \%$ zgromadzonych ksiązek to były ksiązki współczesne, co pozwala zakwestionować opinię o jego ,historyczności".

Spróbujmy - już na zakończenie - podsumować wyniki akcji zainicjowanej przez Hersego. Bez wątpienia mó̇na powiedzieć o jej umiarkowanym powodzeniu: do biblioteki w krótkim czasie wpłynęła znaczna liczba książek, które w istotny sposób wzloggaciły jej zasoby. Nie udało się jednak a sądzić nalézy, że na tym najbardziej burmistrzowi zależało - zbudować księgozbioru, który zawierałby w miarę kompletne piśmiennictwo dotyczące historii i współczesności Wielkiego Księstwa Poznańskiego. Mówiąc inaczej, 
nie udało się nakłonić wydawców, księgarzy i drukarzy, by dobrowolnie przyjęli na siebie powinność dostarczania - raz jeszcze posłuzę się tym określeniem, pamiętając o wszystkich, wyrażonych uprzednio, zastrzeżeniach „egzemplarza obowiązkowego". Ci, do których apel był skierowany, albo zareagowali nań bardzo powściągliwie, albo rzecz całą najzwyczajniej zignorowali. Szkoda, bo w ten sposób przepadła szansa na stworzenie biblioteki, która systematycznie gromadziłaby wydawniczy dorobek całej prowincji, co dziś bardzo ułatwiłoby wszelkiego rodzaju badania nad ruchem wydawniczym i księgarskim Wielkopolski w XIX wieku.

Konfrontacja zapisów zawartych we wspomnianej na początku artykułu bazie rejestrującej dorobek wydawców wielkopolskich z zawartością czterech bibliotek Poznania, których zbiory zostały zaliczone do Narodowego Zasobu Bibliotecznego (Bibliotekia Miejska im. E. Raczyńskiego, Biblioteka Kórnicka PAN, Biblioteka Poznańskiego Towarzystwa Przyjaciół Nauk oraz Biblioteka Uniwersytecka) pokazuje, że łącznie gromadzą one dzisiaj około 55-60\% ówczesnego dorobku wielkopolskich wydawców. Wskazuje to na ogrom czekającej je nadal pracy dla pełnego udokumentowania tego zakresu historii Wielkopolski. 